\title{
Tree Flora of Sabah and Sarawak project - progress and future activities
}

\author{
H.S. $\operatorname{Tan}^{1}$, I. Nadiah ${ }^{1}$, S.S. Eryani ${ }^{1}$
}

Key words

Sabah

Sarawak

Tree flora

\begin{abstract}
Tropical forests in Borneo (Brunei Darussalam, Kalimantan, Sabah and Sarawak) are considered as one of the twelve mega biodiversity centres in the world. However, until now, there is no up-to-date or complete documentation on the flora of the island. The Tree Flora of Sabah and Sarawak Project, jointly undertaken by the Forest Research Institute Malaysia (FRIM), the Forestry Department of Sabah and Forestry Department of Sarawak since 1991, is aimed at providing detailed and up-to-date botanical and ecological information on the tree resources of Sabah and Sarawak. Since its implementation, the project has established a close collaboration with and received generous help from botanists from local and international institutions/herbaria around the world. Up to 2007, a total of 1745 species in 72 families and 267 genera have been revised and published in six volumes of the Tree Flora. These include the discovery and publication of 188 new species in 37 genera and 25 families. In addition, the project also published two Botanical Gazetteers, i.e. Sabah (1995) and Sarawak (2006) Gazetteers. Besides this, the project had carried out a number of activities such as botanical expeditions and various kinds of related workshops to achieve the objectives of the project.
\end{abstract}

Published on 30 October 2009

\section{INTRODUCTION}

The island of Borneo of which Sabah and Sarawak are integral parts is the third largest island in the world. It has been frequently recognized as one of the twelve mega biodiversity centres in the world. The island which occupied a total land area of c. $740000 \mathrm{~km}^{2}$, is conservatively estimated to harbour about $12000-15000$ species of flowering plants of which about 3 500-5 000 are tree species (Soepadmo 1995, Soepadmo \& Wong 1995, Soepadmo 1999, Soepadmo et al. 2006). Since to date there is no complete and systematic documentation of tree flora for Sabah and Sarawak, there is an urgent need to revise and update the taxonomic status of all tree species occurring in the two eastern states of Malaysia.

The Project is jointly undertaken by the Forest Research Institute Malaysia (FRIM), the Sabah Forestry Department and the Sarawak Forestry Department with the following objectives:

- to provide detailed and up-to-date botanical and ecological information of tree resources of Sabah and Sarawak;

- to contribute and enhance fundamental scientific knowledge instrumental for the achievement of sustainable management, conservation and protection of forest tree resources of the country;

- to assist the Government of Malaysia in implementing National Forestry Policy and National Policy on Biological Diversity, and in fulfilling her obligations towards the International Convention on Biological Diversity of which Malaysia is one of the signatories;

- to upgrade national capability in botanical research and in the development of forest tree resources;

- to establish national reference and botanical specimen databases of trees species native to Sabah and Sarawak;

- to conduct detailed botanical and ecological research, inventories, and document the diversity of forest tree resources in Sabah and Sarawak;

\footnotetext{
${ }_{1}^{1}$ Forest Research Institute Malaysia (FRIM), 52109 Kepong, Malaysia.
}

- to disseminate research findings through the publication of eight volumes of the Tree Flora of Sabah and Sarawak and other scientific publications;

- to consolidate and upgrade research capability of young Malaysian botanists in taxonomy, survey, documentation and evaluation of forest-tree resources of Sabah and Sarawak;

- to develop and strengthen the managerial competence of personnel of the herbaria of the participating national institutions.

Since its full implementation in 1993, the project has established a close collaboration with and received helps from botanists of well-established botanical institutions/herbaria such as the Arnold Arboretum, Harvard University, USA (A); Royal Botanic Gardens Edinburgh, UK (E); Royal Botanic Gardens Kew (K); National Herbarium of the Netherlands, University of Leiden branch (L); Singapore Botanic Gardens (SING) and several others.

\section{PROGRESS UP TO 2007}

So far, six volumes of the Tree Flora of Sabah and Sarawak have been published, i.e. Volume 1 (1995); Volume 2 (1996); Volume 3 (2000); Volume 4 (2002); Volume 5 (2004) and Volume 6 (2007) which contained up-to-date accounts of c. 1745 species in 72 families and 267 genera. Out of these, 188 species in 25 families and 37 genera are new to science and 735 species are endemic to Borneo (Fig. 1).

In addition, the project also produced two Botanical Gazetteers, i.e. Sabah (Tangah \& Wong 1995) and Sarawak (Mohizah et al. 2006) Gazetteers. The Gazetteers contain information pertaining the exact coordinates of standardized names of localities and districts in Sabah and Sarawak categorized as: Human Settlements, Hill and Mountain Peaks, Mountain Ranges, Islands, Rivers and Streams, Roads and Protected Areas. In addition, between the year 1993 and 2007, 65 scientific papers have been published by botanists involved in the project in various 


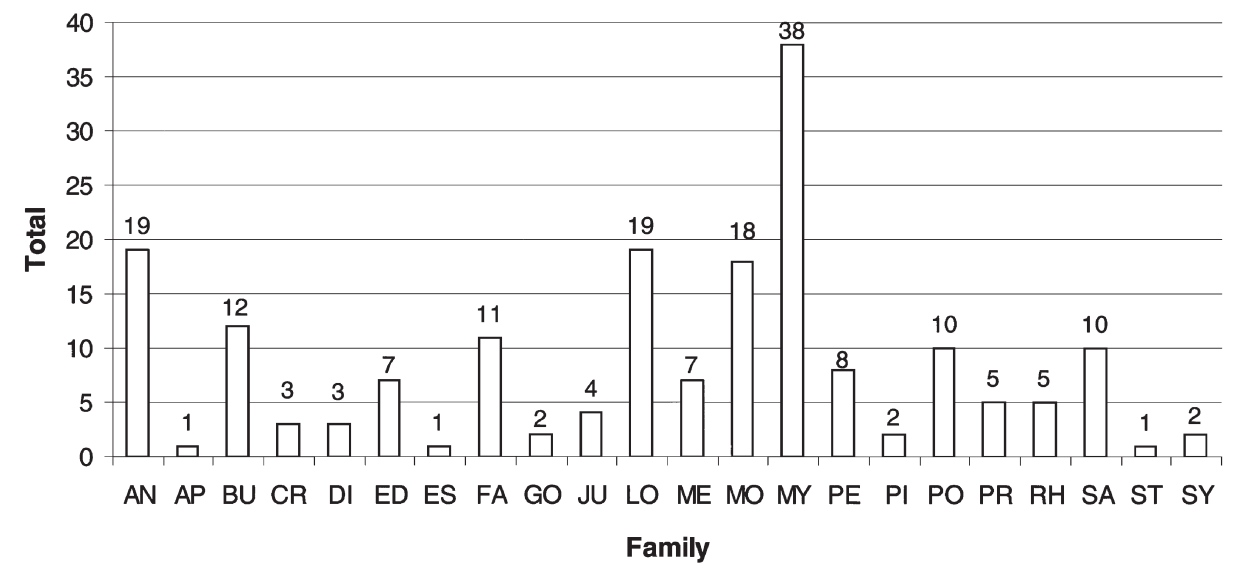

Fig. 1 Numbers of new species in each family. Abbreviations used: $\mathrm{AN}=$ Anacardiaceae; $\mathrm{AP}=$ Apocynaceae; $\mathrm{BU}=\mathrm{Burseraceae}$; CR = Crypteroniaceae; $\mathrm{DI}=$ Dipterocarpaceae $; \mathrm{ED}=$ Ebenaceae $; \mathrm{ES}=$ Escalloniaceae $; \mathrm{FA}=$ Fagaceae $; \mathrm{GO}=$ Goodeniaceae $; \mathrm{JU}=\mathrm{Juglandaceae} ; \mathrm{LO}=$ Loganiaceae; $\mathrm{ME}=\mathrm{Meliaceae} ;$ $\mathrm{MO}=$ Moraceae $; \mathrm{MY}=$ Myrtaceae $; \mathrm{PE}=$ Pentaphylaceae $; \mathrm{PI}=$ Pittosporaceae $; \mathrm{PO}=$ Polygalaceae $; \mathrm{PR}=$ Proteaceae $; \mathrm{RH}=$ Rhizophoraceae $; \mathrm{SA}=$ Sapotaceae $;$ $\mathrm{ST}=$ Staphyleaceae; SY $=$ Symplocaceae.

national and international journals such as, Blumea, Kew Bulletin, Edinburgh Journal of Botany, Garden Bulletin Singapore, Journal of Tropical Forest Science, Sandakania and others.

Since 1993, the project had organized 9 major and 10 minor botanical expeditions to a number of botanically little-known localities in Sabah and Sarawak, such as: Bukit Tawai (1994), Imbak Canyon (2004) and Mt Menkobo (2005), Sabah; and to Lanjak Entimau Wildlife Sanctuary (1997), Usun Apau (2003), Ulu Merirai (2005) and Pulong Tau National Park (2007), Sarawak. These expeditions resulted in the collection of 13716 herbarium collection numbers.

Other activities carried out so far include: establishment of specimen database comprising c. 48880 entries using BRAHMS and related softwares; setting up a botanical reference database currently stands at 3494 entries; and conducting 20 training courses, workshops and seminars on topics relevant to the main objectives of the project.

Between 1993 and 2007, the project has trained/jointly supervised 25 young Malaysian botanists including $6 \mathrm{PhD}$ candidates and $5 \mathrm{MSc}$ candidates attached to FRIM, FRC Sabah, FRC Sarawak and other local as well as overseas universities and botanical institutions.

\section{FUTURE ACTIVITIES AND TARGET}

Future activities are focused on taxonomic revisions of families to be published in TFSS volumes 7 and 8 . These include: Annonaceae, Bombacaceae, Lauraceae, Myrtaceae, Sterculiaceae, Theaceae, Tiliaceae and Verbenaceae (Table 1). First draft manuscripts of certain genera in the families Bombacaceae, Lauraceae, Myrtaceae, Sterculiaceae, Theaceae, Tiliaceae and Verbenaceae have been received and currently are being upgraded and edited. Illustrations (line-drawing) and photographs of selected species are being prepared. As in the

Table 1 List of families being revised for TFSS Volumes 7 and 8.

\begin{tabular}{lrc}
\hline Family & Genus & Species \\
\hline Annonaceae & 33 & 213 \\
Bombacaceae & 5 & 52 \\
Lauraceae & 16 & 206 \\
Myrtaceae & 14 & 205 \\
Sterculiaceae & 11 & 51 \\
Theaceae & 6 & 29 \\
Tiliaceae & 10 & 65 \\
Verbenaceae & 12 & 60 \\
Total & 107 & 881 \\
\hline
\end{tabular}

previous years, botanical expeditions to Sabah and Sarawak and at least one seminar/workshop/training course will be organized in the next 3 years.

\section{CONCLUSION}

Since its full implementation in 1993, the project has benefited many sectors. The main beneficiaries of the project include: Forestry departments, departments of wildlife and national parks, national institutes of higher learning, local, regional and international botanical communities, general publics and private sectors dealing with eco-tourism and wood-based industries.

Tree Flora of Sabah and Sarawak Project is a long term project which requires commitment, collaboration, help and dedicated support from local as well as international botanists currently attached to various institutions and universities. With these supports, it is hoped that the project will be able to achieve its objectives and complete the accounts of the Tree Flora in Sabah and Sarawak.

Acknowledgements We are deeply indebted to the Malaysian Government especially the Ministry of Science, Technology and Innovation (MOSTI), the Overseas Development Administration (ODA) of the United Kingdom and the International Tropical Timber Organization (ITTO) for their generous financial support. We gratefully acknowledge the support of the Director-General of FRIM, the Directors of the Sabah and Sarawak Forestry Departments for their continuous guidance and encouragement. Finally, our thanks are due to the Coordinator and Chief Editor of the project, Dr E. Soepadmo for his cheerful advice and constructive criticism throughout the preparation of this paper.

\section{REFERENCES}

Mohizah M, Julia S, Soh WK. 2006. A Sarawak Gazetteer. Forest Research Institute Malaysia (FRIM) and Sarawak Forestry Department.

Soepadmo E. 1995. Plant diversity of the Malesian tropical rainforest and its phytogeographical and economic significance. In: Primack RB, Lovejoy ThE (eds), Ecology conservation and management of Southeast Asian rainforests: 19-40. Yale University Press, New Haven \& London.

Soepadmo E. 1999. Tree diversity in Borneo: its conservation and management. In: Paranjothy $\mathrm{K}$ et al. (eds), Proceedings of the Symposium on Genetic Resources of Borneo: 5-13. Genetics Society of Malaysia and Universiti Malaysia Sabah.

Soepadmo E, Julia S, Soh WK, Yahud W. 2006. Tree Flora of Sabah and Sarawak - Species diversity and endemism. In: Ho YF, Sarifah KA (eds), Highlights of FRIM's Non-IRPA Projects 2006: 35-52. FRIM.

Soepadmo E, Wong KM (eds). 1995. Tree Flora of Sabah and Sarawak Volume 1. FRIM.

Tangah J, Wong KM. 1995. A Sabah Gazetteer. Forest Research Institute Malaysia (FRIM) and Sabah Forestry Department. 